\title{
SOME CLARIFICATIONS IN THE LAW OF COMMERCIAL PAPER UNDER THE PROPOSED UNIFORM \\ COMMERCIAL CODE
}

\author{
By Fatrfax Leary, JR. $\dagger$
}

For several years the Commissioners on Uniform State Laws and the American Law Institute have been jointly engaged in the preparation of a Uniform Commercial Code. Present plans call for its submission to the legislatures in 1950. Prior to that time its provisions should undergo extensive scrutiny by the legal profession so that the final product can reflect the best solutions of the problems in the law of commercial paper. The scheme of the Code has been outlined elsewhere. ${ }^{1}$ Article III of the Code is entitled "Commercial Paper" and covers the law of bills, notes and checks, together with provisions governing bank collections.

While a complete survey of Article III is beyond the scope of this paper, an exploration of some of the areas of conflict now clarified by express provisions of the Code can be attempted. Dean Beutel has noted over seventy instances of divided authority ${ }^{2}$ under the "act to establish a law uniform with the laws of other states" on the subject of negotiable instruments, hereinafter called the N. I. L. The positions taken on some of these matters in the proposed Uniform Commercial Code, hereinafter called the Code, will be discussed in this and subsequent articles. This paper will cover only the scope of Article III, some provisions settling conflicts as to formal requisites, and some changes suggested in the rules governing indorsement.

$\dagger$ A. B., 1932, Princeton University; LL. B., 1935, Harvard University; member of the bars of New York and District of Columbia; Assistant Professor of Law, University of Pennsylvania.

1. Lewis, The Propsed New Commercial Code, 20 PA. B. A. Q 131 (1949); Beers, The New Commercial Code, 32 J. AM. Jud. Soc'y. 107 (1948) ; Witherspoon, Proposed Steps Toward Uniformity, 53 Com. L. J. 3 (1948) ; Gilmore, On the Difficulties of Codifying Commercial Law, 57 YALO L. J. 1341 (1948); Beers, New Steps Toward Uniformity-The Commercial Code, 20 CoNN. B. J. 80 (1948). The plan envisages separate articles governing Sales, Commercial Paper, Foreign Banking (including letters of credit), Investment Securities, Documents of Title and Chattel Security.

The citations to the Code herein are, unless otherwise specified, from Article III, Proposed Final Draft No. 2, as submitted to the National Conference of Commissioners on Uniform State Laws at the 1948 annual meeting. It is understood that some changes in certain aspects of the Draft are contemplated, but the core is ripe for discussion.

2. Beutel, Problems of Interpretation Under the Negotiable Instruments Law, 27 Neb. L. REv. 485, 495 (1948). 


\section{SCOPE of ARticle III}

The scope of the Commercial Paper article is narrower in some respects than the N. I. L. and broader in others. It is narrower in that it does not purport to cover all types of negotiable instruments and it is broader in that there are express provisions governing the liability of drawees to drawers and vice versa, a considerable area on which the N. I. L. was silent.

\section{Investment Securities}

One of the greatest difficulties of the N. I. I. was its all-inclusive coverage. Section one begins, "An instrument to be negotiable must conform to the following requirements.-" Taken literally the requirements must be met no matter what type of instrument may be involved. The implication is reinforced in the case of corporate securities by the provision in Section 65 expressly providing that the warranties there specified are not made by persons negotiating public or corporation securities. This has caused considerable difficulty in the case of the corporate bond or debenture. ${ }^{3}$ The long term loan in which many lenders participate in the obligation of one borrower, whose borrowings normally are for the purpose of acquiring capital assets, certainly raises problems of a different nature from those involved in financing sales of finished product as in the case of the time bill of exchange, or in the case of borrowings for working capital from a single lender. And clearly the corporate bond and mortgage should be in a different category from the check, the instrument of payment, or the sight draft with bill of lading attached.

For example, in addition to several areas of difficulty over formal requisites, ${ }^{4}$ there is a real need for group action on the part of all bond holders if the corporation should default, and to be effective everywhere, the necessary conditions should appear in the bond. ${ }^{5}$ On policy there may well be a need for preserving some maker defenses, and

3. See Brannan, Negotiable Instruments Law Annotated 7 et seq. (4th ed., Chafee, 1926). But see id. at 210 (7th ed., Beutel, 1948). See also Steffen, A Proposed Uniform Act Making Investment Instruments Negotiabie, 34 CoL. L. REv. 632 (1934).

4. See, e. g., King Cattle Co. v. Joseph, 158 Minn. 481, 198 N. W. 798 (1924), (bond stating that it was "issued under $\dot{A}^{-}$and subject to an indenture - . ." held non-negotiable because not an unconditional promise); Manker v. American Savings Bank and Trust Co., 131 Wash. 430, 230 Pac. 406 (1924) (municipal local improvement bonds providing that holders had no claim against the city "except from the special assessment made for the improvement for which said bond was issued . " held non-negotiable because the promise was to pay out of a particular fund and hence was not unconditional). See Steffen \& Russell, The Negotiability of Corporate Bonds, 41 YALE L. J. 799 (1932).

5. Compare cases such as Guilford v. Minneapolis, S. Ste. M. \& A. Ry., 48 Minn. 560. 51 N. W. 658 (1891), with Allan v. Moline Plow Co., 14 F. $2 d$ d 912 (8th Cir. 1926). On whether the average investor pays any attention to such clauses, see the realistic remarks of Learned Hand, J., in Babbit v. Read, 236 Fed. 42, 44 (2d Cir. 1916). 
perhaps even the "no action" clause in the indenture of trust securing the issue. ${ }^{6}$ On the other hand, free transferability cutting off ownership claims of holders is necessary for the operation of a securities market. The result has been a conflict in decisions and technical interpretations as in Enoch v. Brandon, ${ }^{7}$ where the New York Court of Appeals ruled that the promise was not rendered conditional by a clause in the bond referring to a mortgage in these words: "to which reference is hereby made for a description of the property mortgaged and pledged, the nature and extent of the security, the rights of the holders of the bonds with respect thereto, the manner in which notice may be given to such holders and the terms and conditions upon which said bonds are issued and secured." (Emphasis supplied.)

British courts have had greater freedom since their statute was more clearly an act relating to bills, notes and checks. ${ }^{8}$ There is considerable force to the argument that from its entire context the N. I. L. should be similarly limited to bills, notes and checks. The reference in Section 65 to public or corporation securities could be treated as too incidental to require that the development of various forms of corporate securities be required to fit the Procrustean bed of the formal requisites of the N. I. L. Nevertheless, the weight of authority is against such an argument. Before the decision in Enoch v. Brandon, interim certificates entitling the holder to a definitive bond, when and as issued, came before the New York courts in Manhattan Co. v. Morgan, ${ }^{9}$ and were ruled not negotiable. Both cases involved the ownership claim of a prior holder. The felt need for at least a quasi-negotiability that would promote transferability by cutting off such ownership claims resulted in the passage of the Hofstader Act in New York, ${ }^{10}$ specifically giving these attributes of negotiability to interim certificates.

Despite the possibility that a line could be drawn between the clauses used in King Cattle Co. v. Joseph, ${ }^{11}$ where the bond was ruled

6. See Rittenhouse v. Lukens Steel Co., $116 \mathrm{~Pa}$. Super. 303, 310, 176 At1. 543, 546 (1935), where the court said: "If the plaintiff were permitted to tie up the quick assets of the corporation, the ability of the corporation to carry on its business would be destoyed." But is it not possible to regard all bondholders as equal venturers in the corporate enterprise who should, as in admiralty, share the loss equally when their ship is grounded on the shoals of financial trouble?

7. 249 N. Y. 263,164 N. E. 45 (1928).

8. The act is entitled "An act to codify the law relating to Bills of Exchange, Cheques, and Promissory Notes." See ByLEs on BILLs 158 (20th ed., Welford, 1939); Bechuanaland Exploration Co. v. London Trading Bank, [1898] 2 Q. B. 658.

9. 242 N. Y. 38,150 N. E. 594 (1926).

10. N. Y. Pers. Prop. Law, Art. $8, \S 260$ et seq.

11. 158 Minn. 481, 198 N. W. 798 (1924). See note 4 supra for the wording of the clause. 
to be non-negotiable and the wording before the court in Enoch $v$. Brandon, counsel advising on the negotiability of bond issues was not in a comfortable position. Minor differences in wording might lead to differentiation from precedent and counsel felt that where such large sums were involved a safer basis for action was necessary. Accordingly, the Hofstader Act was amended to cover the corporate bond specifically. These same pressures also resulted in similar statutes elsewhere. ${ }^{12}$

Consequently, in drafting the Uniform Commercial Code, decision was early made to treat separately the two classes of instruments, commercial paper on the one hand, and investment securities on the other. The proper demarcation could not be made along economic lines based upon the use of the proceeds, whether for capital assets or for working capital or financing sales. The simple promissory note given to a bank could well be used for evidencing a capital loan to a small business. Indeed, a relatively recent development in bank lending is the term loan to larger enterprises for capital purposes. ${ }^{13}$ The decision, therefore, was to differentiate on the basis of whether the investment market was being tapped or the usual sources of commercial finance were being used. Naturally, the distinction could not be drawn on the basis of the market originally tapped for the funds, as this might not be apparent to subsequent purchasers. An objective test based upon the type of the instrument was necessary. Bonds, stocks, debentures were clearly to be covered, and the all-inclusive test adopted was to classify as an investment security every obligation which was one of a class evidencing a share in property in an enterprise or in an issuer's obligation. ${ }^{14}$ Article III, therefore, specifically excludes

12. N. Y. Pers. Prop. LAw, Art. 8, $\S \S 260,262$. Pennsylvania has the original statute. PA. Stat. ANN., tit. 56, \$511 et seq. (Purdon, 1930). California, Canal Zone and Nevada have variously amended N. I. L. 184 to cover the same problem. See Brannan, Negotiable Instruments Law 201 (7th ed., Beutel, 1948). More specialized statutes have also been enacted. Kentucky in its statute governing the issue of securities by rural electric cooperative corporations, provides "All obligations and interest coupons issued pursant to this chapter shall be negotiable instruments." Kx. REv. STAT. $\$ 279.130$ (1948). Alabama has a similar provision for obligations of Electric Membership Corporations. Ala. Code ANN., tit. 18, § 22 (1940).

13. See Jacoby \& Saulnier, Term Iending to Business (1942) passim; Holthausen, Term Lending to Business by Commercial Banks in 1946, 33 FED. REs. BuLL. 498 (1947).

14. Commercial Code, Art. V, $\$ 1$ (Proposed Final Draft No. 2), defining a security as "an instrument in bearer or registered form of a type commonly dealt in upon securities exchanges or markets or commonly recognized in any area. in which it is issued or dealt in as a medium of investment if

(a) it is either one of a class or by its terms is divisible into a class of instruments; and

(b) it evidences a share, participation or other interest in property or in an enterprise or the issuer's obligation on the instrument." 
from its scope Investment Securities as defined in Article V of the Code..$^{15}$

\section{Negotiability by Contract}

Study of the proper scope of a Code covering Commercial Paper led to the conclusion that aside from Investment Securities, no other form of instrument for the payment of money was properly pressing for inclusion in the field of negotiable instruments. ${ }^{16}$ Nevertheless, Article III opens with language less inclusive than the N. I. L., by stating that "Any writing to be a negotiable instrument within this Article must. ..." Contrast this with the former wording "An instrument to be negotiable must conform to the following requirements:..." A negative inference can be drawn from the opening lines of Section 102 of Article III of the Code that there is no necessary legislative prohibition against recognition of new types of negotiable instruments. But Section 102 (2) expressly provides that

"A writing which does not conform to the requirements of this Section $* * *$ is not a negotiable instrument within this Article and cannot be made one by contract or by conduct."

This last provision is intended specifically to preclude "negotiability by contract" or by the insertion of clauses waiving defenses, and the like. As a part of the same plan to exclude attempts to secure negotiability for writings that in substance are conditional sales, chattel mortgages or other types of security devices, Section 102 (1)

(b) provides that the instrument must

"contain an unconditional promise or order to pay a sum certain in money and no other promise, order, obligation or power.given by the maker or drawer except as authorized by this Article. . . ."

The continual reference to "within this Article" of course permits some attributes of negotiability to be given documents of title and Investment Securities, but equally it may not clearly preclude like commonlaw treatment of other writings under various theories of estoppel. ${ }^{17}$

15. Section 102(2), "A writing which does not conform to the requirements of this Section or which falls within the scope of Article V on Investment Securities is not a negotiable instrument within this Article and cannot be made one by contract or by conduct."

16. See text at note 63 infra for a modification of the definition of unconditional promise or order to permit commercial paper of governmental bodies to be limited to the proceeds of a particular source.

17. For example, an express agreement not to raise defenses against an assignee in order to permit financing of the contract was upheld in Elzey v. Ajax Heating Co., 10 N. J. Misc. 281, 158 Ati. 851 (Sup. Ct. 1932), where the defense was breach of warranty. The cases seem to turn on the distinction between mere breach of warranty or failure of consideration where the clause is upheld and a total absence of consideration or fraud, where such clauses are generally ruled to be ineffective. Com- 
Certain provisions relating to security arrangements have a legitimate place in commercial paper. Although Section 102 (1) b of the Code provides that a negotiable instrument may not contain any promise, order, obligation or power not expressly authorized, Section 111, entitled "Terms and Omissions Not Affecting Negotiability," permits a clause stating that security has been given and may be sold upon default, a clause confessing judgment at or after maturity, and a term waiving the benefits of any law intended for the advantage or protection of the obligor.

The Code drafters attempted to clean up negotiable paper, and have all security arrangements covered by separate agreement, ${ }^{18}$ but this could not be accomplished.

In any event, it was found that the difficulties arose under instalment sales and in the attempts' of their finance companies to secure a holder in due course status, divorced from the underlying transaction. ${ }^{10}$ The finance companies' desire to be able to collect free of defenses of non-delivery of the goods, failure of consideration, and breach of warranty and the like, conflicted with their desire for a secured position and the right to repossess the goods upon default. These contracts are normally found in the field of consumer finance, and the known disparity in bargaining power between the consumer and the instalment seller, justifies protection of the consumer. On the other hand, terms not justified in contracts of instalment sale to the ultimate consumer are justifiable when included in the note evidencing a broker's "day loan" or a borrowing of "call money" by a business man from a banker. A part of the feeling against high pressure salesmanship may also have influenced the continuation in a few

pare United States v. Troy-Parisian, 115 F. 2d 224 (9th Cir. 1940) (breach of warranty, clause upheld), with Equipment Acceptance Corp. v. Arwood Can Mfg. Co., 117 F. 2d 442 (6th Cir. 1941) (fraud, clause not enforceable). Where an estoppel certificate accompanies a negotiable note the maxim, "Methinks the lady doth protest too much" seems applicable. On the other hand, compare the very general practice of taking an estoppel certificate in an assignment of a real property mortgage. WALSH, MoRTGAges 256-58 (1934). See Beutel, Negotiability by Contract, 28 ILL. L. REv. 205 (1943). Of course any such trickery as a contract made on one piece of paper with no express warranty and a separate contract of warranty on a second page will not be successful. See E. Z. Heating Co. v. Rubin, 107 Pa. Super. 105, 163 Atl. 335 (1932). (1948).

18. Llewellyn, The Case for a Court Security Agreement, 40 Banking 50

19. The cases generally cited as horrible examples of attempts to create negotiability for complicated contracts often involve installment sales to ultimate consumers. E. $g$., Abingdon Bank \& Trust Co. v. Shiplett-Moloney Co., 316 Ill. App. 79, 43 N. E. $2 \mathrm{~d} 857$ (1942) (sale of tractor to farmer, note held negotiable, actually a conditional sales contract) ; Akron Auto Finance Co. v. Stonebraker, 66 Ohio App. 507, 35 N. E. 2d 585 (1941) (retail sale of automobile Cognovit Note and Chattel Mortgage in one paper, note accelerable upon breach of any of the "covenants" of the mortgage, held non-negotiable). Cf. Note, Negotiability of Conditional Sales Contracts, 57 Y ALE I. J. 1414 (1948). 
jurisdictions under the N. I. L. of the Massachusetts rule making title retaining notes non-negotiable, ${ }^{20}$ and decisions finding that the promise is made conditional by a reference to another contract. ${ }^{21}$ Protection has also been given the instalment purchaser under decisions denying holder in due course status to the finance company by reason of the intimate relationship with the seller. ${ }^{21 a}$

A more direct approach would exclude from negotiability all instruments which are subject to requirements of public filing or recording as a condition of the validity as against creditors of or purchasers from the obligor of any clause or provision therein. ${ }^{22}$ Such a provision will, it is understood, be proposed for inclusion at the next meeting of the American Law Institute and the Commissioners on Uniform State Laws. Its inclusion will permit some greater latitude in security clauses in other instruments.

\section{Relation of Drawer and Drawee}

Although on several principal points, the new Code will be narrower in coverage than the N. I. L., several new areas are also covered. The main new area is the contract between drawer and drawee.

Although some provisions with respect to "cover" by the drawer are found in foreign codes, ${ }^{23}$ the contract between drawer and drawee was not mentioned in the N. I. L. The N. I. L. did have two provisions governing the problem indirectly. Under Section 61 a drawer engages that on due presentment the instrument will be accepted or paid or both, and if necessary proceedings upon dishonor are

20. E. $g_{.}$, Pierce, Butler and Pierce Mfg. Corp. v. Russell Boiler Works, 262 Mass. 242,159 N. E. 625 (1928).

21. See note 63 infra.

21a. Some of the cases are collected in Note, 57 Y ALE L. J. 1414, 1415 n. 8 (1948).

22. Filing or recording of lien or title retaining interests in automobiles is required either by the various conditional sales and chattel mortgage acts or by motor vehicle codes in all but five states, and possibly a sixth, Pennsylvania, where the bailment lease is valid without filing. In most states, filing or recording is required for such chattel security devices. The drafts of the Chattel Security Article of the Code on this point are not as yet published.

23. In French law, for example, Cone de COMMERCE, Art. 116, modifié par le décret-loi du 30 Octobre 1935. See Percerou \& Bouteron, LA Nouvelle Legislation Françatse et INTERnationale de la LetTre de Change, dU Billet à ORdRE ET dU CHèque 26 et seq. (1937). Of course the provision that title to the cover passes by operation of law to the holder is in part inconsistent with the Anglo-American idea that a bill is not of itself an assignment. See Code, Section 502. Professor Jitta in a report preceding the Geneva Conference of 1930 points out that it is hardly necessary to specify an obligation to provide cover where the drawer is a guarantor of acceptance and payment unless title to any cover is to pass to the holder. Despite the argument that such a provision greatly increases the value of a bill Jitta regarded the matter as more properly a part of the law of bankruptcy. See LEAGUE of Nations Document C. 487 , M. 203, 1923, II, 38 et seq. Of nine nations then answering a questionnaire on the subject four desired that title to cover should pass to the holder; four did not and one was doubtful. 
taken the drawer will pay the amount of the instrument. Sections 79 and 114 (4) make the drawer liable without necessity for presentment or notice of dishonor where he has no reason to expect or require that the instrument be accepted or paid. Where a drawer has failed to provide cover, it is perhaps better to hold him liable on the instrument without necessity for presentment, protest, and notice than to create a warranty that cover has been provided. Such a warranty would be broken when made so that the statute of limitations would run from the time of issue, not the time of dishonor. ${ }^{24}$ The same scope of the drawer's liability is, therefore, retained in the new Code. ${ }^{25}$

But a congeries of separate statutes and much common law has heretofore governed the liability of the drawee to drawer and the drawer's duty to the drawee.

The Code regulates this situation in several sections. The first of these, Section $507,{ }^{26}$ delineates the basic contract of drawer and drawee and the essential stipulations that govern in the absence of agreement otherwise. Basic is the engagement of the drawee to the drawer that, when a credit is extended subject to drawings, the drawee will pay to the holder on due presentment all bills drawn in accordance with the understanding and properly indorsed, and will accept all such bills not payable on demand.

24. See, e. g., Moody v. Morris-Roberts Co., 38 Ida. 414, 226 Pac. 278 (1923).

25. Section $506(2)$, "The drawer engages that if the bill is not accepted or paid or both he will pay its amount to the holder or to any indorser who pays it, provided there has been any necessary presentment, notice of dishonor and protest. By drawing without recourse the drawer disclaims this liability."

26. "Section 507. Contract of Drawer With Drawee.

"(1) Unless otherwise agreed a person who extends a credit subject to bills drawn against it engages until the credit is exhausted to pay to the holder on due presentment all bills drawn in accordance with the understanding and properly indorsed and to accept all such bills not payable on demand.

"(2) Unless otherwise agreed bills may be accepted in any order convenient to the drawee.

"(3) Upon proper payment of a bill or certification of a check the drawee may charge the account of the drawer.

"(4) A drawee who in good faith makes payment to the holder may charge the account of the drawer

"(a) according to the original tenor of an altered instrument; or

"(b) according to the completion of an incomplete instrument, even though he knows it was originally incomplete.

"(5) The undertaking of a bank to pay a check is limited to a period of six months after its date unless its terms extend the period. Thereafter in the absence of an effective stop order the bank may at its option pay the instrument.

"(6) A drawee paying an instrument which it may not charge to the drawer's account is subrogated to the rights against prior parties of the holder who has received the payment and to the rights of the drawer, the payee and any subsequent party against such holder arising either on the instrument or out of the transaction in which it was issued or transferred. There is no election of remedies, but the drawee may have only one satisfaction." 
As certification for many purposes is acceptance, ${ }^{27}$ the undertaking to accept only bills not payable on demand adopts the rule of $W$ achtel v. Rosen, ${ }^{28}$ that a bank is under no obligation to certify a check, but that rule is also enunciated expressly in Section 504 (2) relating specifically to checks. The rule appears to be extended, however, by the implication of Section 507, limiting the agreement to accept to bills not payable on demand, to sight drafts and demand bills whether drawn on a bank or on a private drawee.

Charge to the Drawer's Account: With respect to the right of charge to the account of the drawer, Section 507 of the Code provides that the drawee may charge the account upon payment of a bill or certification of a check. The implication is clear that no such charge may be made upon the acceptance of a bill, the intention apparently being that acceptance of bills drawn, for example, under a letter of credit, does not authorize a charge to account. As the relevant subsection does not open with "Unless otherwise agreed" the rule is not variable by contract. By definition, however, a check is a bill drawn on a bank and payable on demand. ${ }^{29}$ Consequently a sight draft drawn on a bank is by implication at least a check, and since the basic agreement provisions of the section are subject to variation by contract, a drawee bank could agree to accept bills payable on demand. Should such a draft be accepted, it would follow that an immediate right of charge would accrue to the drawee. Of course, it could be argued that while a check is a bill payable on demand drawn on a bank, not all demand bills drawn on banks are checks, and reliance could be placed upon the phrase, "Unless the context otherwise requires" in the opening clause of Section 102 (3) defining a check. The situation is not one of frequent occurrence, and, since a payment of a sight draft could have been made and charged to account, acceptance should have the same effect. More serious perhaps is the consequence that the drawer and all prior indorsers might be discharged by acceptance of a sight draft drawn on a bank, since the Code abolishes the former distinction between certification at the holder's request which did discharge prior parties, and certification at the drawer's request which did not. ${ }^{30}$

27. N. I. L. $\$ 187$. Code Section 504 provides:

"(1) Certification of a check is acceptance, but discharges the drawer and indorsers from all prior liability on the check.

"(2) Unless otherwise agreed a bank has no obligation to certify a check."

28. 249 N. Y. 386,164 N. E. 326 (1928).

29. Section 102(3): "Unless the context otherwise requires a writing which complies with the requirements of this Section is . . . (c) A 'check' if it is a bill drawn on a bank and payable on demand; . . ."

30. See note 27 supra. This changes the law, but payees desiring the added liability of the drawer can obtain his accommodation endorsement. 
In the sections relating to bank collections it is provided that a bank may charge its customer's account with the items received in a single day in any order convenient to the bank. But it must charge all of the items received on any one day before charging items received on a subsequent day, ${ }^{31}$ whereas under Section 507 bills may be accepted in any order convenient to the drawee, with no limitation as to the day of presentment. Since under Section 607 (1) acceptance may be deferred without dishonor until the close of the next business day following presentment, some latitude as to acceptance is given the drawee. Where a draft is drawn under a letter of credit, by the terms of Article IV specifically governing letters of credit, acceptance can be deferred for three days without dishonor. ${ }^{32}$ At first sight this might appear to give undue latitude to the drawee, but since the drawee-acceptor of a bill is most usually a buyer, he should be able to decide what obligations he will dishonor. Where a bank is the drawee under a letter of credit or other agreement to accept, a more doubtful issue is raised. However, the bank will in all probability always take the instructions of its customer, and the rule, therefore, should be the same.

The Code settles one minor split of authority on the order of charge to the account. Suppose three checks are simultaneously presented, and in total they overdraw the account, but any two may be paid. Which one should be returned? At common law there was some authority apparently requiring all to be returned. ${ }^{33}$ Since under the Code, Section 507, the undertaking is to pay until the credit is exhausted, and since charge may be made in any order convenient to the drawee, upon the simultaneous presentment of several checks, which in the aggregate overdraw the account, the drawee must pay some of them. Any regulation of the order of selection in this event seems too great a regulation of minutiae and an invitation to litigation should a rushed bank clerk improperly select the checks to be returned.

31. Code $\$ 737(2)$, "A payor bank may charge against the drawer's account the items received in a single day in any order convenient to the bank, but must charge all of the items received on any one day before charging items received on a subsequent day. A demand or unmatured claim against its depositor which the bank calls or accelerates for set off against the depositor's account has the effect of an item received on the day of the call or acceleration."

32. Commerctal Code, Art. IV, §15(1) (Proposed Final Draft No. 1).

33. 1 Morse, Banks AND Banking $\$ 354$ (6th ed. 1928) flatly states that in cases of simultaneous presentment, the bank must pay all or none. See Louisville \& N. R. R. v. Federal Reserve Bank, 157 Tenn. 497, 503, 10 S. W. 2d 683, 685 (1928) (dictum accord). On the other hand, Castaline v. Nat. City Bank of Chelsea, 249 Mass. 192, 143 N. E. 832 (1924) ; Reinisch v. Consolidated Nat. Bank, 45 Pa. Super. 236 (1911); 6 Zollman, BaNks AND BANKING \$3754 (1936 ed.) enunciate the rule that the bank must pay such items in any order it may choose until funds in the account are exhausted. 
Overdue Checks: The problem of the "stale" check has, on occasion, proved bothersome. At some point of time, even at common law, a check became sufficiently overdue so that a payment might not be made in good faith. ${ }^{34}$ In any event, a bank refusing to pay a "stale" check should be protected from a claim that it has broken its contract with the drawer. ${ }^{35}$ Stale check statutes have been adopted in twentysix jurisdictions, fifteen adopting a one year limitation and eleven a six months limitation. ${ }^{36}$ The Code selects the shorter limitation as being far more consonant with the rule requiring prompt presentment of checks lest the drawer be discharged to the extent of the loss. ${ }^{37}$ The general feeling, too, is that a check six months old is properly suspect. $^{38}$ As an operating matter it will be far easier to catch a check six months old because of the difference in the name of the month, than it will a check stale by a year or more, where the only difference from a good check is the last digit in the year. Protection is given the paying bank even under the six months limitation for the Code expressly provides that, in the absence of an effective stop order the bank may at its option pay stale checks. ${ }^{39}$ As between the bank and the drawer this provision seems sound. The drawer has issued the check and is in a position to protect himself by giving the bank a stop order. A clause protecting the bank only when payment of a stale check was made through mistake or inadvertence would only be an invitation to litigation on this issue. Also, the bank may well be in a position to know that the drawer wishes the particular check paid.

Right to Stop Payment: The drawer's right to stop payment was also not regulated under the N. I. L., but has been the cause of much litigation and some statutory provisions.

Section 508 on stopping payment first states the general right of the drawer by timely action to stop payment on a check not yet ac-

34. Morrison v. McCartney, 30 Mo. 183 (1860) ; Lancaster Bank v. Woodward, $18 \mathrm{~Pa} .357$ (1852).

35. Commercial Investment Trust v. Lundgren-Wittensten Co., 173 Minn. 83, 216 N. W. 531 (1927) ; Peninsula Nat. Bank v. Hans Pederson Co., 91 Wash. 621, 158 Pac. 246 (1916).

36. One year, e. g., N. J. REv. Stat., \$7:5-10 (1937): Similar statutes exist in District of Columbia, Florida, Idaho, Kansas, Louisiana, Maine, Michigan, New Mexico, Oklahoma, Vermont, Virginia, Washington, West Virginia and Wisconsin.

Six months, e. g., CAL. Gen. LAws, Act 652, § 16e (Deering, 1937) : Similar statutes exist in Alabama, Arkansas, Georgia, Maryland, Missouri, Montana, Nevada, North Carolina, Oregon and Utah.

37. N. I. L. $\$ 186$, Code Sections 602(2), 604(1) (c).

38. Munn, Encyclopedia of Banking and Finance 150 (4th ed. 1937); cf. 6 ZolLMAN, BANKS AND BANKING \$3801 (1936).

39. Section $507(5)$, note 26 supra. 
cepted or paid. ${ }^{40}$ Subsection two, the most controversial, provides that "An oral direction is effective for only one week after receipt by the drawer of specific request for written direction, and any direction is effective for only six months unless renewed in writing." Statutes have been enacted in twenty-nine states with time limits ranging from one year in two states to sixty days in two. ${ }^{41}$ The great majority have selected six months, and this period has been adopted by the Code. It has the virtue of being consistent with the stale check limitation, so as to avoid an unduly large number of time limits in the Code. No case need be made for some limitation on the effectiveness of stop orders, when it is remembered that checks are presented to banks by the thousands daily, ${ }^{42}$ and can come in over-the-counter at any number of tellers' windows. How long must old stop orders be kept fresh in the memory of the busy tellers? Six months is not harsh on the drawer when the evidence we have indicates that over ninety per cent of the checks written are presented within ten days after issue. ${ }^{43}$

The controversy rages around two points, first, the effectiveness of the oral order, and second, the nature of the bank's obligation and duties. Some of the statutes already mentioned require that the stop order be in writing. The theory is that a written order should have an equally dignified countermand. The trouble is that stop orders are

40. "Section 508. Stopping Payment.

"(1) The drawer may by direction to the drawee stop payment of any instrument payable for the drawer's account until the drawee certifies or otherwise accepts the instrument.

"(2) The direction must be received at such time and in such manner as to afford a reasonable opportunity to act on it. An oral direction is effective for only one week after receipt by the drawer of specific request for written direction, and any direction is effective for only six months unless renewed in writing.

"(3) A drawee who by mistake pays an instrument notwithstanding an effective stop order may recover a payment made to one who knew of the order.

"(4) Although the drawee cannot by contract avoid its obligations under this Section it may make a reasonable charge for stopping payment."

41. One year: PA. Stat. AnN., tit. 7, §819-912 (Purdon, Supp. 1947). Virginia has the same limit.

Six months, e. g., AlA. Code ANN., tit. 5, § 135(1) (1941). Same time limit in Connecticut, Florida, Kentucky, Michigan, Mississippi, Nebraska, Nevada, New Mexico, North Carolina, Tennessee, Utah, Vermont, Washington, West Virginia, Wisconsin.

Ninety days, e. g., N. J. Stat. ANN., tit. $17: 9-14$ (1939). Same time limit in Georgia, Idaho, Louisiana, Maine, Missouri, Montana, Oregon, Wyoming.

Sixty days, e. g., Iowa CODE $\$ 9266.1$ (1939). Texas also has the same time limit. The California Statute specifies no time limit.

42. The daily totals vary from over $1,100,000$ items per day in some Federal Reserve Banks, about 350,000 in large metropolitan banks, to between 700 to 3,000 in the small banks.

43. The Reporter for the Article has stated that a count made for him by one large bank showed that 93 per cent of the checks were less than ten days old. 
usually telephoned to the bank. ${ }^{44}$ The depositor calls the officer having supervision of his account, or some other employee in the bank with whom he has had dealings, especially since he will want to be able to identify himself. Or the call may be referred by the phone operator to a teller charged with responsibility for handling stop orders. The need for cultivating good public relations prevents bank personnel from refusing to speak on the point at all, and any acceptance of the phone call may be construed as a waiver of the right to insist on a writing. ${ }^{45}$ On the other hand, consider the position of the drawer. $\mathrm{He}$ must act rapidly to get his direction to the bank in time to prevent certification or payment, and a telegram, from the bank's point of view, would not adequately identify the customer-anyone could have sent it. On the phone the depositor could answer questions thus making his identity certain. The fear of the bank is the false claim of an oral stop order supported by oral testimony of a fabricated telephone conversation. Candor compels the admission that these fears are not entirely groundless, but the banks feel that a claim of waiver of a statutory requirement may be more difficult to establish than a claim of an oral direction to stop. On the other hand even from the bank's point of view, a claim of waiver would dispense with any need for a writing, while a rule requiring confirmation in writing would permit the bank to show its invariable practice of sending a form letter requesting confirmation in writing. A false claim of an oral stop order would then have two hurdles to surmount, proof of the initial direction and a slip-up in the bank's regular course of business. The drawer's need for speed in stopping payment tips the scale in favor of the validity of the oral direction.

The second issue is the extent of the bank's obligation. Many banks today, in an effort to protect themselves against liability for payment in disregard of an effective stop order, ask their customers to sign forms containing stipulations releasing the bank from liability for paying a check after timely receipt of a stop order. ${ }^{46}$ To the credit of

44. See Moore et al., Legal and Institutional Methods Applied to Orders to Stop Payment of Checks-Legal Method, 42 YALE L. J. 817 (1933). The Washington statute is closest in pattern to the proposed Code, requiring written confirmation within fifteen days. WASH. Rev. STAT. ANN. \$\$3252-1-3252-6 (Remington, 1932). A few statutes require a writing, e. g., California, Iowa, Nebraska and Texas. Alabama, Connecticut and Georgia, for example, require only the renewals to be in writing.

45. E. g., Stanford State Bank v. Miles, 186 S. W. 2d 749 (Tex. Civ. App. 1945).

46. The cases are divided on the effectiveness of those clauses. Upholding the clause: Tremont Trust Co. v. Burack, 235 Mass. 398, 126 N. E. 782 (1920); Gaita v. Windsor Bank, 251 N. Y. 152, 167 N. E. 203 (1929); Cohen v. State Bank of Philadelphia, $69 \mathrm{~Pa}$. Super. 40 (1918). Clause against public policy: Grisinger v. Golden State Bank of Long Beach, 92 Cal. App. 443, 268 Pac. 425 (1928) ; Speroff v. First Central Trust Co., 149 Ohio 415, 79 N. E. $2 d 119$ (1948). 
the banks, it should be said that the clauses usually permit a charge to the account only when the payment was by mistake or inadvertence, though some clauses go as far as attempting to exculpate negligence. Sometimes these clauses are printed in the so-called "deposit contract," or in fine print on the back of the "signature card" given the bank when the account was opened. Pressure for these clauses is in part the result of cases refusing the bank subrogation against the drawer when a payment is made after due receipt of a stop order. ${ }^{47}$ In a most recent case, the Ohio Supreme Court has given a rather unusual ruling. That court in Speroff v. First-Central Trust Co.$^{48}$ first, affirmed a ruling that a clause in a written order to stop payment relieving a bank from liability if it should pay the check "through inadvertency or oversight" was as a matter of public policy not enforceable against the customer. Then, the court sent the case back for a new trial saying:

"However, in its amended answer the defendant, in addition to pleading the purported release, alleges further that it at all times exercised good faith and reasonable care with respect to plaintiff's stop-payment order . .. . . . This court is of the opinion that . . . defendant does state a valid defense in alleging that it exercised good faith and reasonable care. Hence for this reason alone, the judgment sustaining the demurrer is reversed and the cause is remanded to the Court of Common Pleas for trial on that issue."

This seems to place the bank's duty to stop payment, not on the ground of a revocation of the order to pay and hence an absolute duty, but treats the obligation rather as one of diligence and good faith. The distinction between diligence and good faith which avoids liability and protection against payment by "inadvertency or oversight" which cannot be obtained by contract seems difficult to draw but may lie in a difference in the burden of coming forward with the evidence.

As to the validity of the exculpatory clause, the New York Court of Appeals in Chase National Bank v. Battat, ${ }^{49}$ also decided in 1948, held that a bank had no subrogation claim against its depositor in the absence of ratification of the payment. The Court, however, stated that

"We had occasion long since to indicate that a bank may protect itself by contract with its depositor so as to limit liability on a stop payment order. (Gaita v. Windsor Bank, $251 \mathrm{~N}$. Y. 152,155 .) When that has not been done, the common-law liability is absolute in the absence of ratification ...."

47. E. g., Chase Nat. Bank v. Battat, 297 N. Y. 185, 78 N. E. 2 d 465 (1948) ; but cf. Usher v. Tucker Co., 217 Mass. 441,105 N. E. 360 (1914). See Note, 40 Harv. L. REv. 110 (1926).

48. 149 Ohio 415,79 N. E. $2 d 119$ (1948).

49. 297 N. Y. 185,78 N. E. 2d 465 (1948). 
Thus, the New York court seems to prefer exculpatory clause technique expressly rejected in Ohio. On the issue of the payor bank's right to subrogation, the Battat case, decided on motion to dismiss, might be distinguished later on the ground that there was no allegation in the pleadings that the depositor was under an enforceable obligation to the payee to pay the check, and also on the fact that the pleadings appear to have been based upon a theory of recovery for unjust enrichment, rather than upon a theory of subrogation. In any event the case seems wrong in denying recovery with a dictum that a contract stipulation would have permitted a charge to the account. Where a bank pays in disregard of a stop payment order, better policy would seem to require that it take its chances in an action, and be denied the charge to the account. The burden of initiating 'litigation should be on the bank, not on the depositor to compel recredit to the account.

The Code solution is to outlaw any clause attempting to limit liability, but to permit a double-barrelled subrogation to the rights of the holder against the drawer or to the drawer's rights of recovery or damages as if the drawer had made a payment. ${ }^{50}$ Thus, if we suppose that the drawer bought a thousand cases of oranges, warranted first quality, and then stopped payment on his check because two hundred cases were bad, the bank paying the check should have a claim against the drawer for the value of the eight hundred good cases and against the payee for the two hundred bad cases. This right of subrogation is given the bank whenever it makes a payment which it may not charge to the drawer's account, as when it pays after notice of the drawer's bankruptcy, after notice of the drawer's death, under circumstances revoking its authority to pay, or after service of garnishment or attachment with respect to the account.

Abrogation of the bank's right to limit its obligation to obey stop orders by contract can also be justified on the ground that in practice the large depositors, advised by counsel, refuse to sign the proffered stipulation. As a practical matter, therefore, the stipulation binds only the small customers. The author has received advice from several bankers that they do not use the stipulation believing that insistence upon it is bad public relations for their banks. It must be emphasized that subrogation gives the bank no right to charge the account. If amicable settlement is not possible, an action must be brought.

Section 507 (3) of the Code also provides that "A drawee who by mistake or inadvertence pays an instrument notwithstanding an effective stop order may recover a payment made to one who knew of the order." This states the general rule and by implication rejects

50. Section $507(6)$, note 26 supra. 
the rule of some cases holding that recovery may be had where the plaintiff bank sustains the burden of proving that the innocent recipient has not prejudicially changed his position. ${ }^{51}$ The existence of the subrogation remedy, of course, modifies the apparent rigidity of the rule of finality of payment here adopted.

Section 508 (1) of the Code also adopts the prevalent rule that a drawer may not compel a bank to withhold payment on a certified check. $^{\text {51a }}$

Death of Drawer. Does the death of the drawer of a check terminate the drawee's authority to pay? Use of the term drawee's authority to pay complicates the issue by conjuring up agency concepts, under which death would revoke the authority of the bank to act. $^{52}$ But, as has been repeatedly held in New York, the rule must be that only notice of death terminates the authority of the bank to pay checks drawn on it. ${ }^{53}$ This rule the Code adopts, ${ }^{54}$ but goes further to provide that unless the bank is notified not to pay checks, it may, notwithstanding notice, pay checks presented during the ten days following the date of death. Six states have statutes providing that a bank may pay for a limited period after death, varying from a minimum of ten days in Massachusetts and New Jersey to thirty days in Florida, Maine, and Vermont. ${ }^{55}$ The purpose is to further the con-

51. E. g., Turetsky v. Morris Plan Industrial Bank of New York, 22 N. Y. S. 2d 514 (Sup. Ct., App. Term, 2d Dep't 1936). A recent Connecticut case adopts the rule, but decides for the holder because the bank failed to prove that there had been no change of position. Union \& New Haven Trust Co. v. Thompson, 134 Conn. 607, 59 A. 2 d 727 (1948).

51a. See note 40 supra. The common law rule was unanimous when the holder procured certification. See, e. g., Times Square Auto Co. v. Rutherford National Bank, 77 N. J. L. 649, 73 Atl. 479 (1909) ; Steiner v. Germantown Trust Co., 104 Pa. Super. 38, 148 Atl. 180 (1932). There is some conflict where the drawer procures certification. Compare Florida Power \& Light Co. v. Tomasello, 103 Fla. 1076, 139 So. 140 (1932) (no power to stop) and Fiss Corp. v. National Safety Bank \& Trust Co., 191 Misc. 397, 77 N. Y. Supp. 2d 293 (City Ct. N. Y. 1948) (statute not cited) with Sutter v. Security Trust Co., 96 N. J. Eq. 644, 126 Atl. 435 (1924) (dictum that drawer having a good defense can stop). Both New Jersey and New York now have statutory provisions that a bank shall not be required to stop a certified

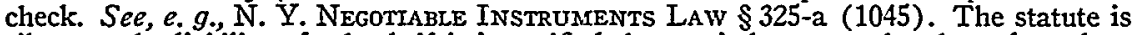
silent on the liability of a bank if it is notified that an indorsement has been forged on a certified check. This is notice that the person in possession is not a holder.

52. See, e. g., Smith v. Simmons, 99 Colo. 227, 61 P. 2d 589 (1936) (Bank having agency powers with respect to customer's bonds).

53. E. g., Glennan v. Rochester Trust \& Safe Deposit Co., 209 N. Y. 12, 102 N. E. 537 (1913).

54. "Section 509. Deatr of Drawer OF CheCK.

"The death of the drawer does not revoke the authority of a bank to pay checks

"(a) for ten days after the date of death unless the bank is notified that checks are not to be paid; or

"(b) thereafter until the bank has knowledge of the death."

55. E. g. MASS. LAwS ANN., c. 107, §17 (1947). Virginia has a two weeks limit. In addition to the states enumerated, there is a statute in Connecticut applying to savings account withdrawal orders only. ConN. GEN. STAT. \$3988 (1930). Connecticut, Maine, Massachusetts and New Jersey have time limits running from the date of the instrument with authority to pay given if death supervenes. The time limits in Vermont, Virginia, and the Code run from the date of death, and thus allow payment of "stale" checks after knowledge of death. 
cept of the check as an instrument of immediate payment and save the holders the necessity of proving a claim in probate. Experience shows that the great majority of these checks are for debts that ultimately are paid and elimination of these useless claims in probate will simplify administration. Of course nothing in the statute prevents the executor from recovering any improper payment from the holder as was done in Burrows v. Burrowes. ${ }^{56}$ Further protection to an estate is given by terminating this authority upon receipt by the bank of a notice not to pay without regard to the source of the notice. The statutory period is too short to permit notice from the executor, as he usually is not appointed in time and it seems desirable that the bank should not be required to determine whether the party giving notice has a legitimate interest. The fact that he gives the notice in the ten day period after death is sufficiently indicative of his interest.

Wrongful Dishonor. Another provision not found in the N. I. L. regulates the liability of the drawee for wrongful dishonor of a bill. Section $510^{57}$ provides that liability for wrongful dishonor is limited to the actual damages proved including any arrest or prosecution of the drawer. The section is worded to cover the case whether the jurisdiction proceeds upon a breach of contract theory or a theory of defamation. Rejecting the common law rule that damage can be "conclusively presumed" without proof where the drawer is a "trader," 58 the section adopts for all drawers the non-trader rule that damages must be proved, but settles one split of authority in favor of liability. Bad check laws are now so common that no result of a wrongful dishonor is more foreseeable than arrest and prosecution of the drawer. Twenty-three states have adopted a statute sponsored by the American Bankers Association requiring actual proof of damages, ${ }^{59}$ but these statutes are silent on the issue of liability for arrest or prosecution.

\section{Formal Requisites}

Under the N. I. L. there has been considerable litigation over the essential requisites of negotiability and several divergent lines of au-

56. 240 Mass. 485, 134 N. E. 271 (1922).

57. "Section 510. Liability of Drawee for Dishonor.

"Where a drawee wrongfully dishonors a bill through mistake or inadvertence the drawer's recovery for defamation or loss of credit is limited to the actual damages proved, including any arrest or prosecution of the drawer."

58. E. g., Browning v. Bank of Vernal, 60 Utah 197, 207 Pac. 462 (1922).

59. E. g., PA. Stat. ANN., tit. 7, \$211 (Purdon, 1939). Similar statutes have been adopted in Alabama, Arkansas, California, Colorado, District of Columbia, Idaho, Illinois, Maine, Massachusetts, Michigan, Mississippi, Missouri, New Jersey, New Mexico, North Carolina, Ohio, Oregon, Tennessee, Virginia, West Virginia, Wisconsin, Wyoming. 
thority have developed. The Code by express provision covers certain of the major divisions, consistently ruling in favor of negotiability.

\section{Seals}

Section 112 settles a conflict under the N. I. L. by specifically providing that, "An instrument otherwise negotiable is within this Article even though it be a sealed instrument." This clearly allows the maker to prove want of consideration as against one not a holder in due course. ${ }^{80}$

\section{Conditional Promises}

The definition of an unconditional promise is enlarged. ${ }^{81}$ On the issue of whether a promise or order is conditional because in effect "an order or promise to pay out of a particular fund," ${ }^{62}$ the Code approves negotiability where the instrument is limited to pay out of the entire assets of the issuing partnership, unincorporated association, trust, or estate. ${ }^{63}$ Negotiability is also conferred on governmentals that are limited in payment to the proceeds of a particular source or

60. N. I. L. $\$ 6(4)$ providing that "the validity and negotiable character of an instrument are not affected by the fact that" it "(4) Bears a seal" was not strong enough language to subject sealed notes to all the incidents of the Act, especially in the matter of the defense of lack of consideration. Compare Balliet v. Fetter, $314 \mathrm{~Pa}$. 284, 171 At1. 466 (1934) (seal precludes defense of lack of consideration), with ItaloPetroleum Corp. v. Hanigan, 40 Del. 534, 14 A. 2d 401 (1940) (defense available). But if a rebuttable presumption promotes circulation of notes, why not a conclusive one where a seal is used? See 26 MICF. L. REv. 208 (1927). Of course, the business man's hostility to the effect of the seal between the immediate parties accounts for the majority rule.

61. "Section 104. When Promise or Order Uncondittonat.

"(1) A promise or order otherwise unconditional is not made conditional by the fact that the instrument

"(a) is subject to conditions not expressly stated therein; or

"(b) states its consideration, whether performed or promised, or the transaction which gave rise to the instrument, or that the promise or order is made or the instrument matures in accordance with or 'as per' such transaction; or

"(c) refers to a separate agreement or indicates that it arises out of such agreement; or

"(d) indicates that it is secured, whether by mortgage, reservation of title or otherwise; or

"(e) indicates a particular account to be debited or any other fund or source from which reimbursement is expected; or

"(f) is limited to payment out of a particular fund or the proceeds of a particular source, if the instrument is issued by a government or governmental agency or unit; or

"(g) is limited to payment out of the entire assets of a partnership, unincorporated association, trust or estate by or on behalf of which the instrument is issued.

"(2) A promise or order is not unconditional if the instrument

"(a) states that it is subject to or governed by any other agreement; or

"(b) states that it is to be paid only out of a particular fund or source except as provided in this Section; or

"(c) otherwise expressly states any condition to its payment."

62. N. I. L. $\$ 3$.

63. Some cases were able to reach this result. E. g., Hibbs v. Brown, $190 \mathrm{~N}$. Y. 167, 82 N. E. 1108 (1907); Nelson Co. v. Morton, 106 Cal. App. 144, 288 Pac. 845 (1930). 
fund. If a theory were to be devised for these additions, it could be said that here the Code recognizes additional commercial entities. This would be proper on the issue of negotiability because the entities so recognized are of the type that are subject to separate credit evaluation in the market, and prospective purchasers are normally in the business of making credit evaluations.

Under the N. I. L. some difficulty has also been experienced over the tendency of the courts to impart a conditional quality to the instrument by construction of language. That the instrument is to serve as an accounting voucher as well as an instrument for the payment of money was recognized by the N. I. L. in provisions permitting, first, an indication of a particular account to be debited, second, a particular fund out of which reimbursement is to be made, and third, a statement of the transaction giving rise to the instrument; ${ }^{64}$ but these three permissions, however, are the only indication given in that law of the proper interpretation of the word "unconditional". Since, in strict form at least, the three exceptions could not be construed as in any way making the promise conditional, the express statutory statement that they were not to have that effect could have been taken as an indication that a strict construction of "conditional" was desired. Commercial practice, however, appears to have tended in a contrary direction, and consequently under the N.I. L. the cases were divided on whether a recital that the instrument was given in return for an executory promise was an implied condition limiting the obligation to pay should the promise be not performed, ${ }^{65}$ or a mere statement of the transaction giving rise to the instrument. ${ }^{66}$ The Code adopts the statement of the transaction view by expressly providing in Section 104 (1) (a) that the promise or order "is not made conditional by the fact that the instrument (a) is subject to conditions not expressly stated therein ..." Literally read this leads to what at first appears to be strange results. Apparently the instrument is admittedly subject to the conditions, and so cannot be enforced free of them. As between the immediate parties this should be the result. The real question is, and should be, whether the holder in due course will take free of the condition. Section 307 (5) (b) provides that knowledge of the fact

64. N. T. L. $\$ 3$.

65. E. g., Ivory v. Lamoreaux, 241 Mich. 226, 217 N. W. 54 (1928); National Bank in Salem v. Morgan, 132 Ore. 515, 284 Pac. 582, 286 Pac. 558 (1930).

66. E. g., Mountjoy Parts Co. v. San Antonio Nat. Bank, 12 S. W. 2 d 609 (Tex. Civ. App. 1928) ; First Bank of Marianna v. Havanna Canning Co., 142 Fla. 554, 195 So. 188 (1940) ; cf. Siegel, Cooper \& Co. v. Chicago Trust \& Savings Bank, 131 I1l. 569,23 N. E. 417 (1890), decided before N. T. L. The apparent diversity can be narrowed by technical distinctions turning on the use of language, but in view of the speed of commercial transactions rules should be drawn which render this sort of interpretation unnecessary wherever possible. 
that an instrument was issued for an executory promise "is not of itself notice" to a purchaser of an infirmity or defect "unless the purchaser has notice of any defense or claim arising from the terms thereof." Section 308 frees the holder in due course from "all claims" to the instrument "on the part of any person" and from "all defenses of any party except" certain real defenses not material here. The apparent intent is that the holder in due course takes free of any defense of nonperformance of the conditions, and this conclusion is buttressed by the preamble to Section 104 (1) (a) that the promise or order is not conditional. ${ }^{67}$

The differences that have arisen over the interpretation of the words "as per" in an instrument, as well as the division of authority under the so-called "full Federal Reserve clause" in a trade acceptance, namely that "The obligation of the acceptor hereof arises out of the purchase of goods from the drawer, maturity being in conformity with the original terms of purchase" are also expressly covered in the Code. Section 104 (1) (b) provides that "A promise or order otherwise anconditional is not made conditional by the fact that the instrument ... (b) states ... that the promise or order is made or that the instrument matures in accordance with or 'as per' such transaction." This accepts the ruling in cases such as State Trading Corporation v. $J_{o r d a n}{ }^{68}$ that the full Federal Reserve clause does not destroy negotiability. But the rule as stated will not, and cannot cover all possible situations involving the use of the words "as per." For example, the proposed provision would not necessarily have changed the results of the three cases arising out of the Reolo frauds. Trade acceptances covering drug shipments were obtained from the purchasers, whose contracts did not oblige them to pay for the goods unless they proved readily saleable. Three purchasers, in signing their acceptances, signed language reading as follows: "Accepted for payment as per

67. There is, however, a difficulty that should be clarified. N. I. L. 57 provided that the holder in due course took free of defect of title and defenses, and by denominating nonperformance of the payee's executory promise a defect, the holder in due course could take free. The danger in the present language is that there is an implication from Code $\$ 104$ (1) (a) that the instrument is subject to a condition, and Section 308 on the rights of a holder in due course only frees him from "claims" and "defenses." Thus, as under the N. I. L., the language may not be strong enough to require a court to change its prior rulings. The condition could be denominated a condition precedent, and thus the burden of pleading and proving performance could be placed on all holders, as nonperformance would thus neither be a "claim" nor a defense. Nor will the language in Code $\S 309$ (b) that lack or failure of consideration is a defense as in an action on a simple contract help, for the rule that performance of conditions precedent must be proved by plaintiff is a rule of the law of simple contracts.

68. 146 Pa. Super. 166, 22 A. 2d 30 (1941). Accord: State Trading Corp. v. Rosen, 126 Conn. 37, 9 A. 2d 289 (1939); States Trading Corp. v. Toepfert, 304 Mass. 473, 23 N. E. 2d 1008 (1939); contra: First Nat. Bank, Statesville v. Power Equipment Co., 211 Iowa 153, 233 N. W. 103 (1930). 
Reolo contract for amount and date shown hereon." In the only one of the three cases in which the author has seen the record, the words "as per Reolo contract" were handwritten above a carat inserted after the word "payment," and the inference is that the phrase was so inserted in the other cases, since the form was printed. The Federal District Court in Minnesota held the acceptance to be unconditional, and that the International Finance Company took free of the defense of nonperformance. ${ }^{69}$ The Maryland court ruled that the important factor was the position of the words "as per." Since the words modified the obligation to pay, defenses were let in, because the acceptance was thus made conditional. ${ }^{70}$ The Pennsylvania Supreme Court, with both prior decisions before it, relied upon a presumption favoring negotiability and accordingly ruled that the acceptance was unconditional. ${ }^{71}$ Under the proposed Code it will still be possible for the Maryland court to rule that a distinction exists between a promise or order "made ... 'as per" " a given contract, and a promise "to pay as per contract." The point to be made is that the Code cannot create a millennium. Problems of interpretation of language will forever remain. The specific reference to the words "as per" in the Code should make all well-advised draftsmen avoid any use of the words except in almost statutory language, but courts must still attempt to work out justice between individuals who have written their documents without benefit of counsel. The frame of reference can now more clearly be whether the "as per" was chosen to modify the obligation to pay or was merely a statement of how the promise came to be made in the first place, with aid given any court desiring to favor negotiability.

\section{The Sum Certain}

Aside from problems of acceleration which require separate discussion elsewhere and problems of costs of collection and attorney's fees, litigation involving the "sum certain" 72 has centered around two 1922).

69. International Finance Co. v. Northwestern Drug Co., 282 Fed. 920 (D. Minn. (1924).

70. International Finance Corp. v. Calvert Drug Co., 144 Md. 303, 124 Atl. 891

71. International Finance Corp. v. Philadelphia Wholesale Drug Co., 312 Pa. 280, 167 Atl. 790 (1933).

72. Code \& 105. Sum Certain

"(1) The sum payable is a sum certain although it is to be paid

“(a) with interest or by stated installments; or

"(b) with different rates of interest before and after default or a specified date; or

"(c) with a stated discount or addition if paid before or after the date fixed for payment; or

"(d) with exchange or less exchange, whether at a fixed rate or at the current rate; or

"(e) with costs of collection or an attorney's fee or both upon default. illegal."

"(2) Nothing in this Section shall validate any term which is otherwise 
principal areas, the discount note and the different rate of interest before and after maturity.

Varying Rate of Interest: The varying rate of interest note has caused more than a little trouble. For example, in First National Bank of Miami v. Bosler, ${ }^{73}$ a suit by an indorsee against the maker, the Pennsylvania Supreme Court had before it a promissory note which contained the following interest provisions, ". . . with interest thereon at the rate of eight per cent per annum from date until fully paid. Interest payable semi-annually . . . Deferred payments are to bear interest from maturity at ten per cent per annum semi-annually." The court held that the note was non-negotiable because it apparently provided for two interest rates after maturity. Since a holder could not tell which would control, the sum was thereby rendered uncertain. The New York Appellate Division was not impressed by this reasoning and refused to hold an identical note non-negotiable. ${ }^{74}$ The New York Court did find, however, that the plaintiff was not a holder in due course. That both notes were obtained from unwary makers during the Florida land boom sales may account for the similarity in result, namely no recovery. Although Professor Chafee has suggested a principle that the meaning of a negotiable note should be clear from the face of the instrument and when it is not, the instrument should not be negotiable, ${ }^{75}$ it is not at all clear to the author why a maker's defenses should be let in against a holder in due course merely because counsel is able to conjure up an ambiguity. Even where some incidental ambiguity actually exists, as to the rate of interest and like matters, denying holder in due course status to this purchaser of an otherwise negotiable note seems incongruous. There is no indication of anything wrong in the original transaction, and no indication that an ambulatory instrument was not intended by the parties.

There is much justification for the majority rule on varying interest rates, that so long as the amount due at the date of maturity is ascertainable, other provisions in aid of collection, if not unlawful, should not destroy negotiability. A lender might well be willing to make a short term loan at a low rate of interest, and if the loan were not repaid, be willing to settle for a rate of interest higher than the original rate but lower than the legal rate, for whatever period might be required to collect. Since a note with interest at three per cent until the date fixed for payment, in many states will draw interest at the

73. $297 \mathrm{~Pa} .353,147$ Atl. 74 (1929).

74. Lessen v. Lindsey, 238 App. Div. 262, 264 N. Y. Supp. 391 (4th Dep't 1933).

75. Brannan, Negotiable Instruments Law Ann. 30 (4th ed., Chafee, 1926). 
legal rate after the due date, ${ }^{76}$ no sound reason appears why a stipulation for a lesser rate should destroy negotiability. The Code would even let the parties change rates of interest prior to maturity, for its provision on the "sum certain" includes a note "with different rates of interest before and after default or a specified date." 77 (Emphasis supplied.)

Indeed, an argument could be made that all stipulations for interest are incidental and should not affect negotiability. It is well known that the price of a note is affected by the rate of interest. If the rate of interest specified in the note is higher than the current rate, other things being equal, the note will command a premium when sold sufficient to make the note yield the current rate to the purchaser. If the rate specified on the note is below the current rate, the price will be at a discount so as to bring the yield up to the current rate. What then of a note calling for interest in the words "at the current rate?" The author is informed that such notes are now being written in the money market. Under the above reasoning, it is argued that the note would always be transferable at face value, and the sum payable would be known at the due date as the face amount of the note would be multiplied by interest at the current rate to determine the total amount to be paid. Nothing in the N. I. L. or in the Code bears specifically on this problem. The N. I. L. provides that a sum is certain although it is to be paid "with interest," and no mention of rate is made. ${ }^{78}$ The Code in Section 105 (1) (a) says "with interest or by stated installments" and subsection (b) provides for the different rates of interest mentioned above. Both N. I. L. and Code specifically confer negotiability on instruments payable "with exchange whether at a fixed rate or at the current rate." ${ }^{79}$ (Emphasis supplied.) Of course, this provision can cut both ways, the specific reference to one "current rate" could by implication exclude other current rates. Or, it could be argued that since the uncertainty engendered by one current rate is not thought to destroy negotiability, the minor differences involved in fluctuations of interest rates should have the same effect. There is, however, one obvious difference in the two situations. On the due date, the rate of exchange from one currency to another is known, but is the "current rate of interest" sufficiently definite and known? Are there not variations between mortgage loans, term loans

76. E. g., Pryor v. Buffalo, 197 N. Y. 123, 90 N. E. 423 (1909).

77. See note 72 sitpra.

78. N. I. L. $\$ 2(1)$.

79. N. I. L. $\S 2(4)$; Code $\S 105(1)$ (d). The Code adds after "with exchange" the words "or less exchange." 
to industry and even between industries? It would seem so, yet these facts are known to those dealing in the money market.

In the note with interest "at the current rate" a problem of interpretation arises. As of what time is the current rate to be taken, the time of making or the date of payment? Or should the interest be calculated periodically as the current rate changes during the life of the note? That is to say, should the note be deemed to bear interest at, say $11 / 4 \%$ for the first six months, that being the current rate at that time, then at $11 / 2 \%$ for the next year and the final period at $13 / 4 \%$ ?

Had the parties meant the rate in existence when the note was made they could easily have expressed the rate. Why then state "at the current rate"? Apparently the borrower wants the protection of a time loan and the lender does not want a long term commitment at present low rates with the indication of increased rates in the near future. Of course, if we adopt the rule that any ambiguity results in non-negotiability, then such notes could be found ambiguous and ruled non-negotiable. On the other hand, the ambiguity of interpretation could be resolved by ruling that on demand notes, interest should be calculated at the "call money" rates in effect from time to time. Time notes, with interest payable in instalments could be held payable at the rate prevailing when the instalment is due. This is merely a note with an increase or decrease in interest at specified dates and so would be negotiable on that ground. Selecting the due date when interest is payable periodically, does not lead to the conclusion that when such is not the case in a time note, the intention is to calculate all interest at the rate in effect when the note is due. Suppose the rate went down instead of up? Would not the fairest result be to calculate interest at the several rates in effect during the life of the note giving neither borrower nor lender an advantage? On such an interpretation what we have is merely a note providing for varying interest rates.

In short, such notes will not be issued, or circulate at such speculative discounts as to bar them from the mercantile currency of the country. Yet the lack of any definite measure of "interest at the current rate" will lead to squabbles over whether a tender was sufficient and so whether indorsers were discharged. Under the rule of the Bosler case, then, such notes would be non-negotiable, but a note calling for interest at the current Federal Reserve re-discount rate, or "the current call money rate plus 3 per cent" on the above analysis should be negotiable.

Discount Note: The discount note has also caused trouble. Typically, it is a promise to pay a definite sum on a given due date with a discount allowed if payment is made within, for example, thirty 
days. ${ }^{80}$ A similar problem arises with the note payable in instalments, but providing for "late charges" if payments are not made on the due date. $^{81}$ A third situation involves the premium to be paid if the maker desires to anticipate any payments. The "late charge" type of note can be classed with other charges after maturity and come under the principle, if such there be, that provisions relating to what happens after maturity or default do not destroy negotiability. These clauses do not come into operation during the circulation of the instrument, and all are designed to ensure actual realization by the holder of the face of the instrument without losses caused by the expense of collecting.

The premium and discount notes are more difficult to justify on such theoretical grounds because these provisions can interfere with the calculation of the present worth of the instrument. Fundamental to any such calculation is the assumption that the note will be paid at maturity. But how is the present worth to be calculated where the instrument reads, "Two years after date I promise to pay to the order of the Last Stove Mfg. Co. the sum of one thousand dollars with a discount of thirty per cent if paid in ninety days"? Technically under the proposed Code such a note is negotiable, as the sum is to be paid "with a stated discount or addition if paid before or after the date fixed for payment." 82 But what would a purchaser pay for it? The answer is that during the first ninety days we have a note for seven hundred dollars and after that date a thousand dollar note. Most makers can be relied upon not to sign notes involving such unusual discounts, and our usury laws and the rules against penalties and forfeitures will protect the few who might, the Code expressly providing that nothing in the sum certain section shall validate any term otherwise illegal. ${ }^{83}$ The cases have normally involved a usual trade discount, and no good

80. Negotiable: Loring v. Anderson, 95 Minn. 101, 103 N. W. 722 (1905) ; Farmers Loan \& Trust Co. v. Planck, 98 Neb. 225,152 N. W. 390 (1915) ; Harrison v. Hunter, 168 S. W. 1036 (Tex. Civ. App. 1914); First Nat. Bank of Iowa City v. Rooney, [1913] 11 D. L. R. 358 (Sask. Sup. Ct.).

Non-negotiable: Waterhouse v. Chouinard, 128 Me. 505, 149 At1. 21 (1930) ; Farmers Loan \& Trust Co. v. McCoy \& Spivey Bros., 32 Okla. 277, 122 Pac. 125 (1912); Nat. Bank v. Feeney, 12 S. D. 156, 80 N. W. 186 (1899).

The Pennsylvania rule cannot be premised with certainty. In Stevens v. Baldy, $67 \mathrm{~Pa}$. Super. 145 (1917) the Common Pleas court ruled a discount note to be negotiable, but the Superior Court in reversing on other grounds expressly left open the issue of negotiability, and the Supreme Court in First Nat. Bank of Miami v. Bosler, 297 Pa. 353, 357, 147 Atl. 74, 76 (1929), by citing with approval an early Michigan case, holding a discount note non-negotiable, may have given some indication of its attitude.

81. Interstate Contracting Co. v. Mager (No. 1), 51 D. \& C. 113 (Pa. C. P., Pike County 1943). This case involved F.H. A. additional charges for processing late payments on an instalment note. These charges can, of course, be distinguished from the discount or addition situation as they only apply after maker has made a default. The court held the note negotiable.

82. Code $\$ 105(1)(c)$, supra note 72.

83. Code $\$ 105(2)$. 
reason appears why a note expressing normal and usual trade terms should not be negotiable, or why the seller who wants to discount his sales should be compelled to go back to the buyer and obtain a note every time the buyer fails to take advantage of his allowances for prompt payment.

The clarifications proposed for the "time certain" provisions are reserved for subsequent discussion with the problem of acceleration.

\section{Problems of Indorsement}

Whether an instrument was payable to bearer, and so could be negotiated by delivery alone, or whether it was payable to order, and required an effective indorsement has raised several difficult questions under the N. I. L. The problem of the "fictitious payee" is so related to the forgery problem that both should be discussed together elsewhere.

\section{Instruments Payable to an Estate}

The human tendency to personify aggregates of assets has led to trouble in the field of decedent's estates where several cases involving notes payable to "The estate of" a named decedent have come before the courts with conflicting results under N. I. I., Section 9. In Bacher v. City National Bank of Philadelphia ${ }^{84}$ such an instrument was ruled by the Pennsylvania Court not to be payable to bearer as it was but a short form for designating the executor for the time being of the estate. In Hansen v. Northwestern National Bank, ${ }^{85}$ the Minnesota Court had previously taken the opposite view. On strictly conceptual reasoning it is easy to agree with Ames that it is "a perversion of language to call the payee in such a note a fictitious or non-existing person," 88 and earlier cases were in accord. ${ }^{87}$ In the actual cases, however, the real issue was, who should bear the loss caused by the wrongdoing of the attorney of the estate. In both of these cases the instrument came into possession of the attorney for the estate, who

84. $347 \mathrm{~Pa} .80,31 \mathrm{~A} .2 \mathrm{~d} 725$ (1943) ; see also Strong v. City Nat. Bank of Philadelphia, $355 \mathrm{~Pa} .390,50 \mathrm{~A}$. 2d 323 (1947). The actual decision in this case was for the defendant, but on the proper issue, namely, whether the bank accepting the check for deposit to the attorney's personal account, where the lawyer had a power of attorney, had actual notice of a breach of trust under Section 9 of the Uniform Fiduciaries Act. Pa. Stat. Ann., tit. 20, §3393 (Purdon, 1923).

85. 175 Minn. 453, 221 N. W. 873 (1928). After the decision, Minnesota amended N. I. L. $\S 8$, by adding "An instrument payable to the estate of a deceased person shall be deemed payable to the order of the administrator or executor of his estate." MiNn. Laws 1929, c. 353. This was not sufficient to compel the court to rule that a note payable to the estate of a named incompetent was order paper. Kluczny v. Matz, 187 Minn. 93, 244 N. W. 407 (1932). The Code $\$ 109$ (1) (e) compels an opposite result. See text infra.

86. Ames, The Negotiable Instruments Law, A Word More, 14 HARv, L. Rev. 442,443 , n. 3 (1900).

87. E. g., Peltier v. Babillion, 45 Mich. 384,8 N. W. 99 (1881). 
indorsed the instrument and then negotiated the instrument in payment of his personal debt. The real issue then was whether the court should make the estate, or the purchaser, suffer for the wrongdoing of the attorney for the estate and be left with a claim against the embezzling attorney. Even under this analysis, however, the Pennsylvania ruling seems preferable on the issue whether the paper was payable to order or to bearer. ${ }^{88}$ Mere entrusting of paper payable to the order of an estate to the attorney for the estate should not constitute a sufficient reason to place liability on the estate. In neither case did the purchaser rely on the subsequently urged bearer character of the instrument in making his purchase, for there was a regular chain of indorsements. The usual rule relating to holding under unauthorized negotiation should apply, and the Code will require its application, because Section 109 (1) (e) makes an instrument payable to "an estate, trust, fund, partnership or unincorporated association ... payable to the order of any person authorized to hold in that behalf." Thus under the Code, an instrument payable to the "Community Chest," or the like would also be order paper requiring a proper indorsement.

\section{Conversion from Bearer to Order Paper}

Another problem which has only been before the courts in three cases, but which has vexed writers and students since the N. I. L. was adopted, is the problem of the conversion of bearer to order paper by indorsement. It is clear that paper which was originally order paper can be converted to bearer paper by indorsement in blank. ${ }^{89}$ Can it thereafter be controlled by a subsequent special indorsement? The N. I. L. is not as clear on this point as it might be. The problem requires that Sections $9(5), 34$ and 40 of the N. I. L. ${ }^{90}$ be interpreted and brought into harmony if possible. One suggested interpretation is that a subsequent special indorsement will control where paper was originally payable to order, but the bearer quality will continue where the instrument was bearer paper on its face. ${ }^{90 \mathrm{a}}$ This solution is based upon

88. See note 84 supra.

89. N. I. L. \$34, "An instrument so indorsed [in blank] . . . is payable to bearer

90. Under N. I. L. 9(5) an instrument is payable to bearer "when the only or last indorsement is an indorsement in blank" and by negative pregnant when neither "only" nor "Iast" is in blank it is not payable to bearer. N. I. L. $\$ 34$, in addition to the part quoted, stipra note 89 , provides that where an instrument is specially indorsed "the indorsement of such indorsee is necessary to the further negotiation of the instrument." Then N. I. I. $\$ 40$ provides "Where an instrument, payable to bearer, is indorsed specially, it may nevertheless be further negotiated by delivery; but the person indorsing specially is liable as indorser only to such holders as make title through his indorsement." See BranNan, Negotiable Instruments Law 628-631 (7th ed., Beutel, 1948). Sections 48 and 88 should also be considered.

90a. See McKeehan, The Negotiable Instruments Law, 50 Am. L. REg. 437, 454462 (1902). 
the theory that the maker of bearer paper contracts for the right to pay any person in possession, and should not be liable to a "true owner" when he pays on a forged indorsement. The three cases raising the point ruled that order paper indorsed in blank continues to be bearer paper, but the cases can perhaps be explained on their facts. ${ }^{91}$ In any event, the Code adopts the view that the special indorsement controls both order paper blank indorsed and paper originally drawn payable to bearer. Section 204 (1) provides "An instrument payable to order and indorsed in blank becomes payable to bearer and may be negotiated by delivery alone until specially indorsed." Section 204 (2) states that "Any instrument specially indorsed may be further negotiated only by the indorsement of the special indorser." These are the only sections bearing on the problem. With the removal of investment securities from the scope of Article III, the argument in favor of maker protection loses much of its validity, as the corporate bond issue with thousands of holders is no longer involved. The interest of holders in protection against loss or theft is apparently thought to outweigh the protection of payment by makers or drawees.

\section{Restrictive Indorsements}

The N. I. L. defines as restrictive an indorsement which prohibits further negotiation, constitutes the indorsee the agent of the indorser, or vests the title in the indorsee in trust for or to the use of some other person..$^{22}$ Despite the fact that several widely diverse factual situations are presented, Sections 37 and 47 of the N. I. L. apparently attach identical consequences to them all. ${ }^{93}$ The law is further com-

91. Parker v. Roberts, 243 Mass. 174, 137 N. E. 295 (1922) ; Christian v. California Bank, 30 Cal. $2 d$ 421, 182 P. $2 d 554$ (1947) ; In re Schmitt's Estate, 288 Ill. App. 250, 6 N. E. 2d 444 (1937). The Massachusetts and Illinois cases involved instruments that were returned to parties prior to the special indorsee without cancellation of the special indorsement and transferred by such prior parties. Defendant's claim that plaintiff had not proved himself a holder was purely technical and received the treatment it deserved. The California case involved an instrument indorsed in blank by an individual and then specially indorsed in the name of a partnership by the same individual and delivered to his partner for deposit in partnership account. Contrary to authority the second partner struck the partnership indorsement and deposited in his personal account in his depositary bank. The holding protected the paying bank, putting the risk of the partner's wrongdoing on the partnership, because "ostensibly one partner has as much right as another to strike a partnership indorsement." The depositary bank, however, was required to stand trial on the ground that it saw the second partner strike out the partnership indorsement and consequently was on notice of possible limitations on his authority to use the check.

92. N. I. L. $\S 36$. The following analysis is based almost entirely on Chafee, Remarks on Restrictive Indorsements, 58 HARV. L. REv. 1182 (1945); STEFFEN, CASES on CoMarercial aNd INVEstarent PAPER (1939) passim; Britton, HaNDBOOK OF THE LAW OF BILLS AND Notes 255-86 (1943); and, of course, upon the Notes and Comments of the Reporter for the Code.

93. N. I. L. $\$ 37$ does recognize a distinction between an indorsement prohibiting further transfer and the other types in subsection (3) allowing the restrictive indorsee to transfer his rights where the form of the indorsement allows him to do so. 
plicated by the fact that the Bank Collection Code has seized upon the concept of restrictive indorsement for the "for deposit", "for collection" and "pay any bank, banker or trust company" type of indorsement; 94 nor can we consider certain of the problems in this field without reference to the Uniform Fiduciaries Act. ${ }^{95}$

On analysis, several factually and functionally different situations are covered by the present idea, "restrictive indorsement:" (1) indorsement prohibiting further transfer; (2) indorsement to an agent of the indorser; (3) indorsement to an agent for a third party; (4) indorsement to a trustee for the indorser; (5) indorsement to a trustee for a third party; and, (6) indorsement for bank collection. Yet these six possible situations can be fitted into three larger categories, the indorsement prohibiting further negotiation, the indorsement to an agent or trustee, and the indorsement for bank collection. At first sight, it may seem unsound to treat the agent and trustee under one heading, but the legal problem, so far as the negotiable instruments law is concerned, is essentially the same. ${ }^{96}$ The problem of bank collections is, in reality, neither an agency nor a trust problem. It is unique and should receive separate treatment. Under the Code each category is separately treated, and the term "restrictive indorsement" is not used.

The Agency or Trust Indorsement: One category of restrictive indorsement is the indorsement to an agent or to a trustee as such. Let us consider the trust indorsement first, supposing a note indorsed by the payee "to $A$ in trust for $B$." Quite apart from the N. I. L. we should, on principles of trust law understand that $A$, when he purchased the note with trust funds, took a legal title subject to the equitable interest of $B$ the cestui que trust, ${ }^{97}$ and that as against prior parties $A$ would have all the rights, privileges and immunities of a bona fide purchaser for value if he qualified as one. Equally, when $A$ sells the note, again apart from the N. I. I., the purchaser would know that he was dealing with a trustee for $B$, because the indorsement to $A$ says so. The purchaser, then will not take free of $B$ 's equities unless the sale is a proper exercise of the trustee's

94. Bank Collection Code $\$ 4$. The statute at present is in force in eighteen jurisdictions, including New York and Pennsylvania. 2 PATON, Digest 1378 (1942).

95. E. g., PA. STAT. ANN., tit. 20, $\$ 3111-3414$ (Purdon, 1930). It is also in force in 19 other jurisdictions. 9 U. I. A. Supp. 104 (1947).

96. The issue is really what effect should be given to the fact that the indorsee holds in a fiduciary capacity for another. The definition of a "fiduciary" in the Uniform Fiduciaries Act $\$ 1$ includes trustee, agent, partner, corporate officer, executor, etc.

97. 1 Scotr, Trusts $\$ 2.3$ (1939). 
trust powers, or of his apparent powers. ${ }^{98}$ Indeed since a negotiable instrument is an ambulatory instrument, it might be argued that the trustee had an apparent authority to sell which would confer holder in due course status upon a purchaser in the absence of notice from other facts of a limitation on the trustee's powers. One of these, of course, would be where the trustee attempts to use such an instrument to pay a personal debt. ${ }^{99}$

But under the N. I. L., Section 37 apparently limits the trustee to bringing any action his indorser could bring, and Section 47 supplies the coup de grace by terminating negotiability when an instrument has been restrictively indorsed. Thus, the trustee is apparently denied an independent holder in due course status, and the postamble of Section 37 gives a purchaser from a trustee only the title that the trustee had. ${ }^{100}$ In apparent disregard of these provisions, the Uniform Fiduciaries Act provides that in the case of an instrument indorsed to a fiduciary as such, a purchaser taking by indorsement from the fiduciary

is not bound to inquire whether the fiduciary is committing a breach of his obligation as fiduciary in indorsing or delivering the instrument, and is not chargeable with notice that the fiduciary is committing a breach of his obligation as fiduciary unless he takes the instrument with actual knowledge of such breach or with knowledge of such facts that his action in taking the instrument amounts to bad faith. ${ }^{101}$

The apparent intent is to confer a good title and a holder in due course status upon the indorsee unless his actual knowledge or bad faith preclude it. Yet even though the indorsee from the fiduciary is "not bound

\section{2 Scotr, Trusts $\$ 288$ (1939).}

99. 2 Scotr, Trusts $\$ 297.6$ (1939). See Uniform Fiductaries Act $\$ \S 4,6,8,9$. Cf. Lloyd v. Sigourney, 5 Bing. 525, 130 Eng. Rep. 1164 (Ex. Ch. 1829) ("Pay to Samuel Williams. . . for my use"). The statute requires actual notice of such use. $C f$. the holding against the cashing bank in Christian v. California Bank, 30 Cal. 2d 421, 182 P. 2d 554 (1947).

100. Cf. Gulbranson-Dickinson Co. v. Hopkins, 170 Wis. 326, 175 N. W. 93 (1919). Compare Union Trust Co. v. Matthews, 258 Mich. 433, 242 N. W. 781 (1931) (parol evidence showed indorsee to be trustee in fact; indorsement therefore restrictive and trustee not holder in due course). But cf. the common law cases treating the indorsement "To $A$ in trust for $B$ " as a special indorsement except that notice of the specific equity of the beneficiary is given. Chafee, supra note 92, at 1202-03. And compare Coral Gables, Inc. v. Jones, $323 \mathrm{~Pa}$. 425, 187 A.t. 434 (1936) (indorsement in fact to trustee but held not restrictive, applying Florida law).

Of course, it can be argued that N. I. L. $\$ 37$, postamble, by selecting the title of the first indorsee not the restricting indorser, indicates a difference, and that therefore $\$ 37$ is not an exclusive listing of the indorsee's rights. Under $\$ 196$ the law merchant would bring in the earlier cases, holding that only notice of the specific equity of the cestui is given. It could also be argued that legislative support for this interpretation can be found in Section 4 of the Uniform Fiduciaries Act. Cf. Landis, Statutes and the Sources of Law, HARV. LeG. ESSAYS 213, 222 et seq. (1934).

101. UnIForar Fiduciaries Act $\S 4$. 
to inquire" and is "not chargeable with notice," the postamble to N. I. L. Section 37 gives him only the title of his indorser. Apparently, therefore, relief from duty of inquiry or from being charged with notice is quite immaterial. ${ }^{102}$

The problem of the indorsement "to $A$ as agent for $B$," bank collections apart, is essentially the same. $A$ should not be limited to the actions his indorser could bring, and a purchaser from $A$ should be able to qualify against prior parties as a holder in due course in his own right if the sale by $A$ is proper. The purchaser from $A$ should, in the absence of notice from sources other than the indorsement itself, be entitled to assume that $A^{\prime}$ 's sale to him is rightful. ${ }^{103}$

Is the situation any different where the indorsement is to $A$ in trust for, or as agent of, the indorser? The purchaser from $A$ should be in the same position. Only actual notice of a breach of $A^{\prime} s$ duty to his cestui que trust or his principal should prevent the purchaser from being a holder in due course. But as to $A$ 's rights against prior parties, the factual situation may be quite different. Where the indorser still has the full beneficial interest, the fiduciary should be limited to any action his indorser could bring. In such a case the fiduciary will have given no value to his indorser and therefore, even as a special indorsee, would acquire no greater rights than his indorser. ${ }^{104}$ But an advance of money to the principal is not inconsistent with being an agent, nor is it inconsistent for the factor to have a lien on the principal's goods for his advances. ${ }^{105}$ In such a case where the goods are negotiable instruments, the agent should be a holder in due course to the extent of his lien.

102. Of course, arguments can be made that N. I. L. $\$ 37$ is not intended to be exclusive, and that the word "negotiable" has several meanings in the Act and its use in N. I. L. $\S 47$ is in a narrow sense. See Smith, The Concept of "Negotiability", 7 TEx. L. Rev. 520 (1929). Equally it can be argued that the words, "until it has been restrictively indorsed," in Section 47 refer only to an indorsement under N. I. L. $\$ 36(1)$. See Chafee, supra note 92, at 1211-1216 (1945).

103. See, e. g., UNIFORM FIDUCIARIES ACT $\$ \$ 4,5,6,7,9$. The general integrity of all fiduciaries entitles them to the benefit of the assumption, and the rule protecting those dealing with a fiduciary's negotiable instruments, in the absence of actual knowledge that such a transaction is unauthorized, will make proper dealing easier for honest fiduciaries. The risk of loss is an honesty risk and, in view of the policy in favor of free circulation of negotiable instruments, should be borne by those selecting the fiduciary.

104. Cases such as First Nat. Bank v. John Morrell \& Co., 53 S. D. 496, 221 N. W. 95 (1928), could reach the same result on the theory that conditional or provisional bank credit is not value. However, the same result has been reached in cases when value was paid. Smith v. Bayer, 46 Ore. 143, 79 Pac. 497 (1905). The contrary view has been reached where value was given to the restrictive indorser who was the beneficiary of the indorsement on the theory that by accepting value he waived the restrictive character of the indorsement, and so, apparently the words of restriction could be stricken under N. I. L. \$48. Continental Nat. Bank \& Trust Co. v. Stirling, 65 Idaho 123, 140 P. 2d 230 (1943) ; Glens Falls Indemnity Co. v. Palmetto Bank, 104 F. 2d 671 (4th Cir. 1939). The reasoning is not very satisfactory.

105. To avoid circuity of action the agent should not be permitted to recover more than the amount of his advances. 
All of the arguments protecting the purchaser dealing directly with the fiduciary apply a fortiori to remote indorsees. Such persons should be entitled, in the absence of actual notice of something wrong, to assume that the transaction between the fiduciary and their predecessor in title was proper. Certainly the known integrity of most fiduciaries makes such an assumption a reasonable one.

The Code, therefore, quite properly gives an indorsement to an agent or trustee the full effect of a special indorsement to such person, but although he has power to negotiate the instrument he remains subject to his fiduciary obligation. ${ }^{100}$ Thus, the question whether the fiduciary can qualify as a holder in due course, or can by sale create such a status in a purchaser, is referred to the sections dealing with what constitutes a holder in due course and what facts constitute notice to the purchaser. Here the Code adopts the approach of the Uniform Fiduciaries Act, the purchaser is not put on notice by the mere fact that he is dealing with a fiduciary; actual notice is required. ${ }^{\mathbf{1 0 7}}$

The Indorsement Prohibiting Further Transfer: The indorsement, "pay to $A$ only," is well handled under the N. I. L. It creates a method whereby a holder can prevent the creation of a subsequent holder in due course status which would cut off his ownership rights. Chafee suggests that the indorsement "makes $A$ a sort of messenger boy to carry the instrument to the primary party and bring back the cash." 108 But, it is submitted that the Code properly does not require $A$ to do this physically. He can transfer the instrument to others to do it for him, but there can be no new holder in due course under such an indorsement, with one exception not material here. ${ }^{109}$

106. "Section 207. INDORSEMENT to AgENT OR IN Trust.

"Unless it is for bank collection, an indorsement which states that it is for collection or to an agent in trust or otherwise for the benefit or the account of the indorser or another named person has the full effect of a special indorsement to the person named as indorsee, and he can further negotiate the instrument but remains subject to any obligation as a fiduciary."

107. $\S 307(3)$ (c). "The purchaser has notice of a defect in the title when he has reason to know . . that a fiduciary has negotiated the instrument in payment of or as security for his own debt or in any transaction for his own benefit or otherwise in breach of duty."

$\$ 307(5)$ (e). "Knowledge of the following facts does not of itself give the purchaser notice of an infirmity or defect ... that any person negotiating the instrument is or was a fiduciary."

108. Chafee, supra note 92 , at $1201 \mathrm{n} .22$.

109. "Section 205. Conditional Indorsement; ProHibiting Transfer.

"Neither a conditional indorsement nor one purporting to prohibit further transfer of the instrument prevents its further negotiation, and the holder may enforce payment in disregard of the limitation; but after such an indorsement there can be no subsequent holder in due course and the indorsee or any subsequent holder takes the instrument or its proceeds subject to any rights of the indorsee."

See also CODE $\$ 716$. 
The Indorsement for Bank Collection: Under the N. I. I. the indorsement to a bank "for collection" was denominated restrictive, and the cases were divided on the indorsements reading "for deposit" or "pay any bank, banker or trust company." 110 Of course, where "for account of" a third party was added to the indorsement, N. I. L. Section 36(3) compelled a ruling that the indorsement was restrictive. The Bank Collection Code specifically makes the "for deposit" and the "pay any bank, banker or trust company" indorsements restrictive. ${ }^{111}$ Under the N. I. L. it is difficult to see how a bank taking under such an indorsement can become a holder in due course in its own right. And this is correct where a bank takes an instrument in its collection department, giving no credit to its customer, or takes a cash item and posts a credit to its customer's account, but tells him not to draw against the credit until the item is paid. ${ }^{112}$ But the reason it is correct is because the bank has not paid value. Where the bank in good faith pays value to its customer before maturity of the instruments handled, no sound business reason appears why it should be denied the rights of a holder in due course. ${ }^{113}$ Value may consist in permitting withdrawals against cash items or in advancing credit available for immediate withdrawal against the customer's outstanding collections. ${ }^{114}$ Yet a customer indorsing "for deposit" or the like is properly entitled to protection against two types of risk. First, he is entitled to protection against loss on the way to the bank or against attempts by his employees to "cash" the items and abscond with the proceeds. ${ }^{115}$ This should be equally true where the customer names no indorsee, but writes "for deposit" and signs his name. Second, even where the customer has received value from his

110. The cases are collected in BrItron, CASES on BILIS AND Notes 148 n. 5-6 (1941).

\section{Bank Collection Code $\$ 4$.}

112. The Code, in the sections on bank collections adopts the position that provisional credit is not value. Code $\$ 714(1)$. But cf. Note, Bank Credit as Valtie, 57 Y ALE L. J. 1149 (1948). Banks are quite insistent upon their right to dishonor instruments drawn against uncollected funds and any claim of a value position, therefore, comes with poor grace from them.

113. See the cases permitting restrictive wording to be stricken, supra note 104 . Cf. Atlantic City Nat. Bank v. Commercial Lumber Co., 107 N. J. L. 492, 155 Ati. 762 (1931) (reaching the same result on an estoppel theory). But cf. Cohen v. Friedberg, 56 A. $2 \mathrm{~d} 571$ (N. J. Sup. Ct. 1948) (check cashing agency making advances under agency arrangement for collection can not become holder in due course).

114. See Code $\$ 714$ and 720. Note, Bank Credit as Value: The Commercial Code Article III, 57 Y ALE L. J. 1419 (1948).

115. Cf. Graham v. Southington Bank \& Trust Co., 99 Conn. 494, 121 Atl. 812 (1923) (checks payable to bank cashed improperly-bank liable) ; Christian v. Calfornia Bank, 30 Cal. 2d 421, 182 P. 2d 554 (1947) (bank put on notice by removal of "for deposit" indorsement). 
bank, some limit must be placed on what his bank can do with the item. Assume a demand note transferred by an indorsee customer to his bank "for collection." The bank advances the full amount, against the note pending collection. If we permit the bank to shift the financing risk by selling the note to, or securing an advance from another bank, it should only be from a bank which would handle the note in normal course of collection. ${ }^{116}$ Any other transfer would extend the time required to make demand and consequently would extend the customer's secondary liability, subjecting him to additional risks. Lipschutz v. Philadelphia Savings Fund Society, ${ }^{117}$ protecting a bank making advances against deposited checks, can be considered properly decided only because the record discloses that the protected bank regularly handled the checks for the bank in which they were deposited; thus the depositor received firm credit at an earlier date, and his contingent liability risk was not extended.

The Code provides that the indorsement "for deposit" and the like, accompanied by transfer to a bank locks the instrument in banking channels, ${ }^{118}$ and the detailed regulation of bank collections found in Part VII of Article III gives the depositor the protection discussed above. Here again the Code avoids the difficulty of the concept of the restrictive indorsement by not using the term.

116. Circuitous routing should be avoided. Spamr, The Clearance and ColLECTION OF CHECKS 103 et seq. (1926).

117. $107 \mathrm{~Pa}$. Super. 481, 164 Atl. 74 (1933). It is doubtful if depositors consciousiy believe that they are stipulating for protection against the insolvency of their bank by indorsing "for deposit." Further, if the "float" of uncollected checks is available for credit, timely advances to a bank with frozen assets may stave off insolvency. The banking system functions when only a small portion of deposit balances are withdrawn at one time. A bank failure generates runs on other banks. It is, therefore, good social policy to prevent bank failures, and this may permit a weighing of this interest against giving fullest possible protection of the depositor.

118. "Section 206. Indorsement for Bank Collection.

“(1) An indorsement stating that it is 'for credit', 'for collection' or 'for deposit' or the like and naming a bank as indorsee is an indorsement for bank collection. A like indorsement naming no indorsee has the same effect when the instrument is transferred to a bank by or for the indorser.

"(2) After an instrument has been indorsed for bank collection no person may become a holder in due course until the instrument has been transferred to the bank."

This section may be changed somewhat in scope by the current revisions but it is believed that the basic policy will remain the same. 